\title{
El Caso Almonacid. La Noción de una Obligación Imperativa de Derecho Internacional de Enjuiciar Ciertos Crímenes y la Jurisprudencia Interamericana sobre Leyes de Impunidad
}

Este comentario, junto a los documentos que analiza, está disponible en www.anuariocdh.uchile.cl

José Zalaquett Daher*

\section{Introducción}

Con fecha 26 de septiembre de 2006, la Corte Interamericana de Derechos Humanos (en adelante, la Corte) emitió sentencia en el caso Almonacid Arellano y otros vs. Chile (en adelante, Almonacid o el Caso Almonacid ).

El caso versa, en lo sustancial, sobre la aplicabilidad del Decreto Ley de Amnistía publicado el día 18 de abril de 1978 por la Junta Militar que había asumido, de facto, el gobierno de Chile el día 11 de septiembre de 1973. Este es el cuarto caso en contra de Chile que la Corte ha decidido. Los otros tres tratan de la violación de las obligaciones impuestas por la Convención Americana sobre Derechos Humanos (en adelante, la Convención Americana) de respetar y garantizar el derecho de libertad de expresión ${ }^{1}$.

Almonacid constituye el paso más reciente en la evolución de la doctrina del sistema interamericano de protección de derechos humanos sobre la ilegitimidad, ilegalidad e inaplicabilidad de medidas legales que impiden la investigación, procesamiento y eventual sanción por violaciones a los derechos humanos consideradas particularmente graves por el derecho internacional. Dichas medidas son conocidas comúnmente como leyes de amnistías, de autoamnistía o de impunidad.

En este comentario se sostiene que:

a. Almonacid representa un avance significativo en la evolución conceptual y de argumentación normativa que sobre esta materia ha tenido el sistema interamericano y, en especial, la Corte.

b. La conclusión principal a la que la Corte arriba en este caso es enteramente correcta, a la luz del desarrollo del Derecho Internacional. Esta es, en síntesis, que existen ciertos crímenes de suprema gravedad, respecto de los cuales dicha rama del derecho establece obligaciones imperativas de investigación, persecución, juzgamiento y eventual sanción; que tales crímenes no prescriben ni pueden ser objeto de amnistías u otras medidas legales que impidan que se cumplan tales obligaciones; que los Estados no pueden invocar normas de derecho interno para excepcionarse de esas obligaciones y que existe una obligación internacional para los Estados de cooperar entre sí con el fin de asegurar el cumplimiento de ellas.

c. Sin embargo, la fundamentación de la Corte para llegar a tales conclusiones es a la vez limitada e imprecisa. Como se verá más adelante es, en cierta medida, inevitable que sea limitada por el modo cómo la Corte ha fallado sobre su propia competencia. En efecto, la Corte no toma en cuenta el concepto de crímenes de guerra, que emana tanto del Derecho Internacional Humanitario, sobre

* Codirector del Centro de Derechos Humanos, Facultad de Derecho, Universidad de Chile.

1 Estos tres fallos recayeron sobre: (i) El Caso "La Ultima Tentación de Cristo" (Olmedo Bustos y otros) vs. Chile. Sentencia de 5 de febrero de 2001. Serie C No 73. (ii) El Caso Palamara Iribarne vs. Chile. Sentencia de 22 de noviembre de 2005. Serie C No 135. (iii) El Caso Claude Reyes y otros vs. Chile. Sentencia de 19 de septiembre de 2006. Serie C No 151. 
cuya aplicación ha declarado no poseer competencia. Tampoco considera cabalmente el Derecho Penal Internacional ni el desarrollo del pensamiento ético y jurídico que ha surgido con ocasión del nacimiento y desarrollo de la disciplina y campo de experiencia que se conoce con el nombre de "justicia transicional" o "verdad, justicia y reconciliación", entre otras denominaciones. Al no hacer uso de estos importantes marcos normativos y conceptuales (sin perjuicio de que las razones puedan ser explicables o atendibles) la Corte se priva de argumentos más sólidos y coherentes para llegar a las conclusiones generales -básicamente correctas- que alcanza. La argumentación de la Corte, además, construye una obligación de investigar, perseguir y castigar ciertos crímenes principalmente a partir de determinadas disposiciones que contiene la Convención Americana. Por cierto, ello supone que la Corte afirma, indirectamente, que el Derecho Penal Internacional, a diferencia del derecho penal nacional de los distintos Estados, no sólo establece una facultad punitiva a favor de éstos, sino que impone una obligación de investigación, prosecución y castigo que pesa sobre los Estados y sobre la comunidad internacional. Sin embargo, dado que la Corte tampoco se vale, consistentemente, del marco normativo del Derecho Penal Internacional o de doctrinas penales determinadas, algunos alcances de tal obligación punitiva resultan imprecisos.

\section{El desarrollo del Derecho Internacional de postguerra, en cuanto a la protección de la per- sona humana y la obligación de investigar, someter a proceso y, eventualmente, castigar ciertos crímenes gravísimos}

Ha llegado a ser ampliamente reconocido en la literatura contemporánea jurídica y sobre relaciones internacionales lo siguiente: (i) que el orden internacional post Segunda Guerra Mundial contiene, desde sus orígenes, un esencial componente normativo de carácter humanitario, el cual se basa en la proposición de que la protección y promoción de la persona humana, principalmente de cara al poder político o en una situación de enfrentamiento bélico, es una obligación de la comunidad internacional toda; (ii) que esta circunstancia ha modificado significativamente el concepto internacional de soberanía de los Estados tal como prevalecía hasta entonces, así como la noción de sujeto y objeto del Derecho Internacional; (iii) que las principales ramas de dicho componente internacional humanitario de postguerra son el Derecho Internacional de los Derechos Humanos (que se incorpora plenamente al Derecho Internacional a partir del año 1948), el Derecho Internacional Humanitario (que si bien formaba parte del Derecho Internacional desde la segunda mitad del siglo XIX, experimenta un gran avance a partir de los Convenios de Ginebra de 1949 y de otros desarrollos normativos posteriores) y el Derecho Internacional de los Refugiados, que surge en 1950; (iv) que, asimismo, en los años de postguerra emerge (mucho más allá de los escasos precedentes históricos que suelen citarse) un Derecho Penal Internacional, tanto sustantivo como procesal, cuyo desarrollo tuvo un impulso inicial en los años inmediatamente posteriores a la Segunda Guerra Mundial y fue seguido de un período de algunas décadas de progreso esporádico y en áreas específicas (mayoritariamente en el campo de la normativa internacional contra el terrorismo) para culminar en una nueva oleada de avance sistemático, a partir de la década de los noventa del siglo XX; (v) que todo lo anterior responde, en lo fundamental, a un progreso de la conciencia ética y jurídica internacional, impulsado inicialmente por un rechazo categórico a los extremos de inhumanidad que se dieron en el marco de dicho conflicto ( $y$, previamente, durante el ascenso del régimen nazi) así como por una determinación de la comunidad internacional de no permitir la repetición de tales hechos.

El Derecho Penal Internacional sustantivo de los años de postguerra tuvo su punto de partida en las normas internacionales y jurisprudencia generadas a propósito de los juicios de Nuremberg y Tokio, como bien se explica, en síntesis, en Almonacid ${ }^{2}$. Aunque el interés de la Corte en ese

2 Párrs. 95 a 98. 
punto es exponer solamente los orígenes del desarrollo del concepto de crimen contra la humanidad $^{3}$ (presumiblemente porque opina que escapa a su jurisdicción pronunciarse sobre materias humanitarias que no calzan, estrictamente, dentro de la noción de derechos humanos), los hechos que sintetiza en esos pasajes de la sentencia dieron lugar a la formulación de postguerra de una tríada de ilícitos contra el Derecho Internacional: crimen contra la humanidad, crimen de guerra y crimen contra la paz (o crimen de agresión). Paralelamente, la Asamblea General de las Naciones Unidas, adoptó con fecha 9 de diciembre de 1948, la Convención para la Prevención y la Sanción del Delito de Genocidio ${ }^{4}$. Por su parte, los Cuatro Convenios de Ginebra, de 1949, tipificaron las graves transgresiones en contra del Derecho Internacional Humanitario que constituyen crímenes de guerra ${ }^{5}$.

Las tensiones de la emergente Guerra Fría condujeron, desde principios de los años cincuenta, a un congelamiento del primer impulso de avances en materia de justicia penal internacional de los años de postguerra, que habían tenido una expresión sustantiva en los desarrollos mencionados y, por cierto, una dimensión procesal representada por la constitución y funcionamiento de los tribunales ad hoc de Nuremberg y de Tokio.

Más tarde, se reanudó el proceso de avances normativos. En 1968, la Asamblea General de Naciones Unidas adoptó la Convención sobre la Imprescriptibilidad de los Crímenes de Guerra y de los Crímenes de Lesa Humanidad'́. Junto con establecer la obligación de los Estados parte de adoptar legislación para declarar la imprescriptibilidad de dichos crímenes y para facilitar su extradición, esta convención caracteriza a los crímenes de guerra y a los crímenes contra la humanidad 7 .

3 Muchos han reconocido que el más remoto antecedente de derecho internacional de esta noción puede hallarse en la Ilamada Cláusula de Martens, contenida en las Convenciones de La Haya de 1899 y 1907 y reiterada, en el tiempo de postguerra, en las normas de los Cuatro Convenios de Ginebra de 1949 y del Protocolo I, adicional a dichos convenios, de 1977, así como en el preámbulo del Protocolo Adicional II, del mismo año. Así lo declara acertadamente el juez Cançado Trindade en su voto concurrente en el caso Barrios Altos (párrs. 22 a 25). La Corte también cita el precedente de la Cláusula de Martens en Almonacid (párr. 94). Dicha cláusula establece que en lo no prescrito expresamente por el derecho internacional humanitario, las personas civiles y los combatientes quedan bajo la protección y el imperio de los principios del derecho de gentes derivados de los usos establecidos, de los principios de humanidad y de los dictados de la conciencia pública. El propio Cançado Trindade ha sostenido que la conciencia jurídica universal es la fuente material par excellence del propio Derecho Internacional (voto concurrente citado, párr. 14).

4 Resolución 260 A (III).

5 Los Cuatro Convenios de 1949 contienen en común el mismo artículo 3, aplicable a conflictos armados internos. Si bien esta escueta normativa ha sido posteriormente ampliada por las disposiciones del Protocolo II Adicional a Los Convenios de Ginebra de 1949, de 1977, la fecha de los hechos que dieron lugar al caso Almonacid (16 y 17 de septiembre de 1973) es anterior. De los cuatro Convenios de Ginebra de 1949, los más pertinentes a un caso de conflicto armado interno son los Convenios III y IV. Las normas sobre punición de crímenes de guerra más relevantes del Convenio III son las de los artículos 1, 2, 3, 129, 130 y 131. Respecto del Convenio IV, las más relevantes se consagran en los artículos $1,2,3,146,147$ y 148 .

6 Resolución 2391 (XXIII), de 26 de noviembre de 1968.

7 Artículo I: Los crímenes siguientes son imprescriptibles, cualquiera que sea la fecha en que se hayan cometido:

a) Los crímenes de guerra según la definición dada en el Estatuto del Tribunal Militar Internacional de Nuremberg, de 8 de agosto de 1945, y confirmada por las resoluciones de la Asamblea General de las Naciones Unidas 3 (I) de 13 de febrero de 1946 y 95 (I) de 11 de diciembre de 1946, sobre todo las "infracciones graves" enumeradas en los Convenios de Ginebra de 12 de agosto de 1949 para la protección de las víctimas de la guerra;

b) Los crímenes de lesa humanidad cometidos tanto en tiempo de guerra como en tiempo de paz, según la definición dada en el Estatuto del Tribunal Militar Internacional de Nuremberg, de 8 de agosto de 1945, y confirmada por las resoluciones de la Asamblea General de las Naciones Unidas 3 (I) de 13 de febrero de 1946 y 95 (I) de 11 de diciembre de 1946, así como la expulsión por ataque armado u ocupación y los actos inhumanos debidos a la política de apartheid y el delito de genocidio definido en la Convención de 1948 para la Prevención y la Sanción del Delito de Genocidio aun si esos actos no constituyen una violación del derecho interno del país donde fueron cometidos. 
Tradicionalmente, el concepto de crimen de guerra ha sido más claramente determinable, en la medida que los Cuatro Convenios de Ginebra de 1949 y el Protocolo I Adicional a dichos convenios, de 1977, contienen normas expresas que taxativamente señalan qué conductas constituyen infracciones graves a las obligaciones que imponen. En cambio, el concepto de crimen contra la humanidad experimentó una compleja evolución ${ }^{8}$ hasta que el Estatuto de Roma de 1998 (el cual contiene numerosas disposiciones de Derecho Penal Internacional sustantivo, junto con las de carácter procesal, que establecen la Corte Penal Internacional) sistematizó y amplió este concepto. En su artículo 7 se establece que son crímenes contra la humanidad cualquiera de los numerosos actos que allí menciona (entre ellos, por cierto, el de asesinato, que fue el crimen perpetrado contra el Sr. Almonacid Arellano) "cuando se cometa como parte de un ataque generalizado o sistemático contra una población civil y con conocimiento de dicho ataque".

El mismo Estatuto de Roma tipifica separadamente el crimen de genocidio (aunque se trata estrictamente de un crimen contra la humanidad) por el simbolismo histórico y la relevancia legislativa que este crimen singular ha tenido en el Derecho Internacional. En cuanto al crimen de agresión (parte de la ya mencionada tríada de postguerra) el Estatuto atribuye competencia a la Corte Penal Internacional, pero difiere su definición ${ }^{9}$.

En lo que toca a la prescripción, el artículo 29 del Estatuto de Roma declara que los crímenes de competencia de la Corte Penal Internacional son imprescriptibles, reafirmando categóricamente un principio que emanaba previamente de interpretaciones doctrinales y del texto de algunos instrumentos, como la Convención sobre la Imprescriptibilidad de los Crímenes de Guerra y de los Crímenes de Lesa Humanidad y la Convención Interamericana Sobre Desaparición Forzada de Personas.

En cambio, el Estatuto de Roma no hace referencia clara a algún principio de inamnistiabilidad. De hecho, la única norma internacional relevante que se refiere expresamente a la amnistía es la del artículo 6.5. del Protocolo II, Adicional a los Convenios de Ginebra de 1949, que dispone lo siguiente:

8 Además de la definición emanada de los desarrollos descritos en la nota al pie 7, letra a), el artículo II de la Convención Para la Prevención y la Sanción del Delito de Genocidio, de 1948, define este crimen como sigue: En la presente Convención, se entiende por genocidio cualquiera de los actos mencionados a continuación, perpetrados con la intención de destruir, total o parcialmente, a un grupo nacional, étnico, racial o religioso, como tal: a) Matanza de miembros del grupo; b) Lesión grave a la integridad física o mental de los miembros del grupo; c) Sometimiento intencional del grupo a condiciones de existencia que hayan de acarrear su destrucción física, total o parcial; d) Medidas destinadas a impedir los nacimientos en el seno del grupo; e) Traslado por fuerza de niños del grupo a otro grupo.

Por su parte, la Convención Internacional sobre la Represión y el Castigo del Crimen de Apartheid, de 30 de noviembre de 1973, en su artículo I dispone: 1. Los Estados Partes en la presente Convención declaran que el apartheid es un crimen de lesa humanidad y que los actos inhumanos que resultan de las políticas y prácticas de apartheid y las políticas y prácticas análogas de segregación y discriminación racial que se definen en el artículo Il de la presente Convención son crímenes que violan los principios del derecho internacional, en particular los propósitos y principios de la Carta de las Naciones Unidas, y que constituyen una amenaza seria para la paz y la seguridad internacionales. 2. Los Estados Partes en la presente Convención declaran criminales las organizaciones, las instituciones y los particulares que cometen el crimen de apartheid. El artículo II de la misma Convención tipifica conductas específicas que constituyen crimen de apartheid.

En el ámbito de las Américas, la Convención Interamericana sobre Desaparición Forzada de Personas, de 1994, reafirma en su preámbulo que la práctica sistemática de desapariciones es un crimen contra la humanidad.

9 El artículo 5.2. del Estatuto de Roma establece que: “La Corte ejercerá competencia respecto del crimen de agresión una vez que se apruebe una disposición de conformidad con los artículos 121 y 123 en que se defina el crimen y se enuncien las condiciones en las cuales lo hará. Esa disposición será compatible con las disposiciones pertinentes de la Carta de las Naciones Unidas". 
"A la cesación de las hostilidades, las autoridades en el poder procurarán conceder la amnistía más amplia posible a las personas que hayan tomado parte en el conflicto armado o que se encuentren privadas de libertad, internadas o detenidas por motivos relacionados con el conflicto armado".

Respecto de esta disposición, en mi opinión, la interpretación más razonable no es que ella procura otorgar impunidad respecto de crímenes de guerra, sino que, dado que quienes se alzan en armas en contra de un gobierno establecido no gozan, de acuerdo al Protocolo II, de los privilegios de prisioneros de guerra si son capturados (entre ellos el privilegio de no ser juzgados por el solo hecho de combatir), dicha norma busca alentar la pacificación, instando a que se otorgue a quienes hayan tomado parte en el conflicto armado la más amplia amnistía posible.

El principio de inamnistiabilidad de crímenes de guerra y de crímenes contra la humanidad (incluyendo, por cierto, al genocidio) no brota, por tanto, de inequívocas normas expresas, sino de interpretaciones (a mi juicio, en general, bien fundadas) de normas del Derecho Internacional de los Derechos Humanos, del Derecho Internacional Humanitario y del Derecho Penal Internacional.

El principal ímpetu a favor de estas interpretaciones se ha dado en los últimos 24 años, desde los comienzos del gobierno del Presidente Alfonsín, elegido en 1983, luego de siete años de dictadura militar en la República Argentina. Dicho proceso político marcó el inicio de una tendencia internacional a enfrentar el legado de crímenes de guerra o graves violaciones de los derechos humanos cometidos en el contexto de un gobierno dictatorial o de conflictos armados internos, como parte del necesario proceso de construcción o reconstrucción de un sistema democrático viable y justo. La mencionada tendencia, que fue de la mano de los fenómenos de transición política o de culminación de conflictos armados internos que proliferaron en todas las latitudes, en tiempos coetáneos y posteriores al proceso de fin de la Guerra Fría, ha dado lugar a un cúmulo de experiencias nacionales e internacionales sobre comisiones de verdad, reparaciones, justicia y perdón respecto de graves crímenes de motivación política cometidos en el pasado reciente. Muchas de estas experiencias pueden ser consideradas fallidas o seriamente incompletas, en tanto que algunas otras han alcanzado, en medida más significativa, los propósitos preventivos, reparativos y de fortalecimiento democrático que se proponían. Todos esos casos han dado lugar a intensos debates y acciones políticas y judiciales a nivel nacional, a la creación de organizaciones internacionales no gubernamentales -entre las que destaca el Internacional Center for Transitional Justice- y a una abundante literatura académica ${ }^{10}$. En su conjunto, ello constituye el campo conocido corrientemente como "justicia transicional" (traducción de la expresión en inglés transitional justice que, a mi juicio, es inapropiada en ambos idiomas), "verdad, justicia y reconciliación" o "lucha contra la impunidad".

No es posible, en el espacio de este comentario, dar cuenta cabal de la relación entre este nuevo campo de acción y de estudio y el desarrollo de la noción de inamnistiabilidad de crímenes de guerra. Baste decir que dentro de dicho campo han ido ganando aceptación ciertas nociones fundamentales, entre ellas las siguientes: (i) que el propósito de enfrentar un legado de graves violaciones de derechos humanos o crímenes de guerra es, en último término, contribuir a la construcción o reconstrucción de un sistema político justo, viable y respetuoso del estado de derecho y de los derechos humanos; (ii) que con ese fin es necesario revelar la verdad sobre los

10 Quienes se interesen por el tema, pueden comenzar por consultar algunas compilaciones generales. Entre ellas destaca la obra en tres volúmenes Transitional Justice: How Emerging Democracies Reckon With Former Regimes, editado por Neil Kritz. Washington D.C.: United States Institute for Peace, 1995. Más recientemente, puede citarse la compilación sobre un aspecto específico de este campo The Handbook of Reparations, editado por Pablo de Greiff, Oxford University Press, 2006. En cuanto a sitios institucionales, debe mencionarse el del International Center for Transitional Justice (www.ictj.org). 
más graves crímenes cometidos en el contexto del pasado dictatorial y/o de conflicto armado, promover el más amplio reconocimiento social sobre tal verdad, proveer reparaciones a las víctimas o sus familiares, hacer justicia e introducir reformas políticas, legales e institucionales, así como programas de educación que tiendan a garantizar la no repetición de tales hechos; (iii) que dentro tales criterios los Estados tienen un margen de discreción, de acuerdo a las circunstancias específicas que viven y a la evolución de éstas; (iv) que, no obstante, no existe margen de discreción en lo que toca a impartir justicia en materia de crímenes de guerra y de crímenes contra la humanidad, dado que constituyen obligaciones perentorias de las que los Estados no pueden eximirse invocando leyes de amnistía o de autoamnistía; (v) que el hecho que un gobierno determinado no se encuentre en situación de cumplir con dicha obligación no exime la responsabilidad que le cabe al Estado ante el Derecho Internacional por tal incumplimiento ni cancela la obligación de intentar darle efectividad, si se presentaren circunstancias más propicias; (vi) y que, en todo caso, nunca sería lícito que los nuevos gobernantes confirmen, condonen o aumenten la situación de impunidad que han heredado.

En relación con la afirmación de un deber imperativo de investigación, procesamiento y punición de tales graves crímenes y de la ilegitimidad de leyes de amnistía y, más aún, de autoamnistía, algunos han creído ver un resurgimiento de las teorías retribucionistas sobre justificación de la pena, en oposición a las teorías sobre prevención especial o general, que gozaron de una aceptación virtualmente indisputada hasta hace algunas décadas. Si bien es cierto que las teorías retribucionistas han reverdecido en años recientes ${ }^{11}$, se puede sostener la obligación imperativa ya mencionada también sobre bases consecuencialistas, afirmando que la conciencia universal ha hecho el cálculo costo-beneficio de una vez y para siempre, sobre la convicción de que en ninguna circunstancia imaginable la completa impunidad de tales conductas podría, en definitiva, generar mejores resultados sociales que su prosecución y castigo.

Retomando la línea principal de este comentario, no es una circunstancia menor, dentro del ambiente de opinión en que opera el sistema interamericano, que la mayoría de las experiencias más citadas y estudiadas de políticas respecto de crímenes del pasado durante procesos de transición democrática hayan tenido lugar en Argentina, Chile, El Salvador, Guatemala y Perú.

\section{La Evolución de la Jurisprudencia Interamericana sobre Leyes de Impunidad}

La Comisión Interamericana de Derechos Humanos fue establecida ya en los instrumentos fundacionales de la Organización de Estados Americanos, aunque la Convención Americana, de 1969, amplió sus facultades. Este mismo instrumento creó la Corte, la cual fue establecida efectivamente en 1979. Sin embargo, sus primeras sentencias sobre casos contenciosos datan de 1987, debido principalmente a la renuencia de la Comisión de enviar casos a la Corte durante sus primeros años de funcionamiento.

Es también en la década de los ochenta que la Comisión comienza a procesar más sistemáticamente casos individuales, alcanzándose, en años recientes, una cifra superior a las mil peticiones anuales. Aunque solamente una fracción de estos casos llega a la Corte, el trabajo de ésta se ha intensificado enormemente en los últimos años.

Como se advierte, la marcada mayor actividad del sistema interamericano coincide, aproximadamente, con los procesos de democratización que tuvieron lugar en la mayoría de los países de la región. En muchos casos, Ilegaron al gobierno de dichos países personas que, desde la oposición

11 Su más destacado proponente, a mi juicio, es el filósofo Thomas Nagel, profesor de New York University. 
a los regímenes dictatoriales, habían enfatizado la primacía de los derechos humanos. Diversos gobiernos reconocieron la jurisdicción de la Corte, comenzaron a participar activamente y de modo razonablemente constructivo en el sistema interamericano, aceptaron soluciones amistosas en casos ante la Comisión e incluso se allanaron a demandas en su contra presentadas ante la Corte. Asimismo, distintos gobiernos presentaron como candidatos a la Comisión y a la Corte a personas de reconocidas credenciales en materia de derechos humanos. Por su parte, muchas organizaciones nacionales de derechos humanos de países americanos adquirieron experiencia en litigar casos ante estos órganos.

Como resultado de todo lo anterior, se comenzaron a presentar ante el sistema interamericano numerosos casos que datan de los tiempos de la dictadura o del conflicto armado interno, en los respectivos países de la región.

Uno de los temas de mayor relevancia ha sido el de la vigencia, legitimidad o aplicabilidad de medidas legales de impunidad heredadas por los gobiernos civiles o adoptadas por éstos.

A este respecto cabe referirse a tres hitos relevantes, con anterioridad al caso Almonacid.

(a). Caso Velásquez Rodríguez vs. Honduras. Sentencia de 29 de julio de 1988. Serie C No 4

Este caso seminal de la jurisprudencia de la Corte no versa sobre leyes de impunidad. Sin embargo, su importancia radica en la doctrina sobre el contenido de la obligación de garantizar los distintos derechos humanos contenidos en el artículo 1.1. de la Convención Americana. En este caso la Corte dijo:

"La segunda obligación de los Estados Partes es la de "garantizar" el libre y pleno ejercicio de los derechos reconocidos en la Convención a toda persona sujeta a su jurisdicción. Esta obligación implica el deber de los Estados Partes de organizar todo el aparato gubernamental y, en general, todas las estructuras a través de las cuales se manifiesta el ejercicio del poder público, de manera tal que sean capaces de asegurar jurídicamente el libre y pleno ejercicio de los derechos humanos. Como consecuencia de esta obligación los Estados deben prevenir, investigar y sancionar (énfasis añadido) toda violación de los derechos reconocidos por la Convención y procurar, además, el restablecimiento, si es posible, del derecho conculcado y, en su caso, la reparación de los daños producidos por la violación de los derechos humanos"12.

Esta caracterización de la obligación de garantizar es una de las bases jurídicas recurrentes en los informes de la Comisión y en los fallos de la Corte, incluyendo aquellos sobre leyes de impunidad.

\section{(b). Informe de la Comisión Interamericana sobre la Ley de Impunidad de Uruguay ${ }^{13}$}

Este informe se pronunció sobre diversas peticiones que tenían en común una denuncia de los efectos jurídicos de la Ley № 15.848 de Uruguay, de 22 de diciembre de 1986, y su aplicación por el Poder Judicial. En su artículo primero, esta Ley establece lo siguiente:

"Reconócese que, como consecuencia de la lógica de los hechos originados por el acuerdo celebrado entre Partidos Políticos y las Fuerzas Armadas en agosto de 1984, y a efecto de concluir la transición hacia la plena vigencia del orden constitucional, ha caducado el ejercicio de la pretensión punitiva del Estado respecto de los delitos cometidos hasta el $1^{\circ}$ de marzo de 1985 por funcionarios militares

\footnotetext{
12 Velásquez Rodríguez vs. Honduras, párr. 166.

13 Informe $N^{\circ}$ 29/92, casos 10.029, 10.036, 10.145, 10.305, 10.372 10.373, 10.374 y 10.375, Uruguay, 2 de octubre de 1992.
} 
y policiales, equiparados y asimilados, por móviles políticos o en ocasión del cumplimiento de sus funciones y en ocasión de acciones ordenadas por los mandos que actuaron durante el período de facto".

Dicha ley se aprobó mediante mecanismos constitucionales y la proposición de revocarla o derogarla fue derrotada en un plebiscito convocado al efecto, de acuerdo a lo que permite la Constitución de Uruguay. Ante ello, la Comisión aclaró que no emitía juicio sobre los procesos legislativos internos del Uruguay sino sobre la compatibilidad de dicha legislación con las obligaciones internacionales contraídas por ese Estado al haber ratificado, en 1985, la Convención Americana.

En su informe ${ }^{14}$, la Comisión se refiere a los hechos que han quedado impunes por medio de la promulgación de dicha ley en los siguientes términos: "presuntas desapariciones de personas que han sido ampliamente condenadas como violaciones de derechos humanos particularmente graves (énfasis añadido) y secuestros de menores, entre otros; por lo que la necesidad social de su esclarecimiento e investigación no puede ser equiparada a la de un mero delito común"15. Como se advierte, la Comisión no intenta caracterizar los crímenes como ilícitos en contra del derecho Internacional, sino que sólo alude a su especial gravedad.

Luego, la Comisión se extiende sobre el derecho a garantías judiciales establecido en el artículo 8.1 de la Convención y el derecho a la protección judicial dispuesto en su artículo 25, declarando que dichos derechos asisten a las víctimas o sus familiares para obtener justicia y el esclarecimiento de los hechos. También se refiere a la jurisprudencia del caso Velásquez Rodríguez sobre la obligación de garantizar y, en particular, a uno de sus aspectos, la obligación de investigar.

Como conclusión, el Informe establece que la Ley $N^{0} 15.848$ es incompatible con el artículo XVIII (Derecho de justicia) de la Declaración Americana de los Derechos y Deberes del Hombre, y los artículos 1, 8 y 25 de la Convención Americana sobre Derechos Humanos, y recomienda al Estado de Uruguay otorgar a las víctimas o a sus derecho-habientes una justa compensación y adoptar medidas para esclarecer los hechos e individualizar a los responsables de las violaciones de derechos humanos ocurridas durante el gobierno de facto.

La Comisión no solicitó al Estado de Uruguay tomar medidas para que no se aplicara la Ley № 15.848 ni tampoco envió el caso a la Corte.

\section{(c). Caso Barrios Altos (Chumpibuma Aguirre et al. vs. Perú).}

En este caso se impugnan la ley del Perú № 26.479, que amnistía en general las violaciones de derechos humanos cometidas en el período 1980-1995, y la ley $N^{\circ} 26.492$, que específicamente establece la impunidad sobre los hechos que dieron lugar al caso.

Esta sentencia, pronunciada el 14 de marzo de 2001, esto es, más de ocho años después del informe de la Comisión Interamericana recién citado sobre la ley № 15.848 de Uruguay, representa un cambio en el tratamiento de la materia que comentamos. En la sección VII del fallo, la Corte se extiende sobre la incompatibilidad de las leyes de amnistía con la Convención Americana, en la medida en que estén encaminadas a prevenir la investigación y castigo de graves violaciones de derechos humanos tales como tortura, ejecuciones extrajudiciales, sumarias o arbitrarias y desapariciones forzadas, todas ellas prohibidas porque violan derechos no derogables.

14 Informe 29/92, párrs. 28-51.

15 Ídem, párr. 38. 
La Corte reitera y amplía las consideraciones ya conocidas sobre los artículos 1.1, 8 y 25 de la Convención, agregando una referencia al artículo 2, que impone a los Estados la obligación de adoptar medidas legislativas y de otro carácter para hacer efectivos los derechos y libertades que en ella se establecen.

La Corte determina, además ${ }^{16}$, que las "leyes de autoamnistía" son manifiestamente incompatibles con la Convención. Declara que ellas atentan contra el derecho a garantías judiciales y el derecho a la verdad (que en su concepto está subsumido en la obtención de clarificación de los hechos ocurridos mediante el ejercicio de los derechos contemplados en los artículos 8 y 25 de la Convención Americana, sobre garantías judiciales y protección judicial, respectivamente $)^{17}$.

En suma, aun cuando Barrios Altos apunta hacia una obligación de esclarecer y castigar ciertos crímenes, se refiere a ellos como aquellos que violan derechos no derogables. Esta expresión, que proviene de una traducción literal del inglés, significa derechos que no pueden ser objeto de suspensión, ni aun en caso de guerra u otra emergencia legalmente declarada ${ }^{18}$. Sin embargo, no todo derecho "no derogable" es un derecho absoluto. Por ejemplo, la tortura está prohibida en toda circunstancia; en cambio, puede existir una causal de justificación para privar de la vida (derecho "no derogable") a otro, sea en tiempo de normalidad o emergencia, si se actúa en legítima defensa o se da muerte en combate a un soldado enemigo, en el contexto de un conflicto armado. Por otra parte, tampoco toda violación de un derecho "no derogable" constituye un crimen contra la humanidad, de acuerdo a la evolución que se ha reseñado más arriba en este comentario. En efecto, un asesinato o acto de tortura aislado, que no es cometido en el contexto de un ataque sistemático o masivo contra la población civil, y con conocimiento de dicho ataque, sería, sin duda, un acto abominable que merecería el severo calificativo de "crimen", pero no necesariamente de "crimen contra la humanidad", si nos atenemos al artículo 7 del Estatuto de Roma.

Frente a estas consideraciones se puede decir, con razón, que las violaciones que dieron lugar al caso Barrios Altos sí reúnen los criterios para calificarlas de crimen contra la humanidad. Sin embargo, en este punto la Corte argumenta sobre conceptos generales y su razonamiento es, por tanto, impreciso. En Almonacid, caso que se examina a continuación, la Corte mejora significativamente su argumentación, pero mantiene la limitación de su fundamentación jurídica y algunas imprecisiones.

\section{El caso Almonacid}

Al analizar este caso, el enfoque se dirigirá a la materia que es objeto de este comentario, sin abordar otros puntos de interés como la decisión que rechaza la excepción preliminar interpuesta por el Estado y fundada en la supuesta falta de competencia de la Corte para conocer de hechos anteriores a la ratificación de la Convención Americana por parte de Chile, en 1991.

Los hechos relevantes del caso son los siguientes. El señor Almonacid Arellano fue detenido y baleado por efectivos de la policía el día 16 de septiembre de 1972, esto es, cinco días después del golpe militar, y murió al día siguiente, a consecuencia de sus heridas. Sus familiares iniciaron acciones judiciales ante la justicia ordinaria del crimen para obtener el esclarecimiento de los hechos y el castigo de los responsables, con fecha 4 de noviembre de 1992, esto es, con posterioridad al restablecimiento de la democracia en Chile, el 11 de marzo de 1990. El 5 de diciembre de 1995,

\footnotetext{
16 Sentencia Barrios Altos, párr. 44.

17 Ídem, párr. 47.

18 Tales derechos están especificados en el artículo 27.2 de la Convención Americana.
} 
la Corte Suprema de Chile decidió que la justicia militar era competente para seguir conociendo del caso. El 28 de enero de 1997, el Segundo Juzgado Militar de Santiago dictó sobreseimiento total y definitivo, aplicando el Decreto Ley de Amnistía № 2.191, de 18 de abril de 1978.

La Corte Interamericana declaró que "al pretender amnistiar a los responsables de delitos de lesa humanidad, el Decreto Ley № 2.191 es incompatible con la Convención Americana y, por tanto, carece de efectos jurídicos, a la luz de dicho tratado" ${ }^{\prime 19}$.

Ahora bien, el decreto Ley de Amnistía pretendía cubrir crímenes cometidos entre el 11 de septiembre de 1973 y el 18 de abril de 1978, incluyendo muchísimos actos que pueden, con propiedad, calificarse de crímenes de lesa humanidad, entre ellos, principalmente, las sistemáticas y masivas violaciones de derechos humanos perpetradas por la Dirección de Inteligencia Nacional (DINA) -servicio de inteligencia del gobierno militar, que estuvo a cargo de centralizar la represión política entre fines de 1973, fecha de su efectiva creación, hasta 1978, fecha de su formal disolución y su reemplazo por un nuevo órgano de inteligencia denominado Central Nacional de Informaciones (CNI)-. Entre las políticas represivas diseñadas y ejecutadas por la DINA se cuentan los asesinatos políticos y la práctica sistemática de la tortura y de las desapariciones forzadas.

Sin embargo, el asesinato del Sr. Almonacid Arellano puede caracterizarse más apropiadamente como crimen de guerra que como crimen contra la humanidad. Por cierto que el reproche moral es semejante en ambos casos y los efectos jurídicos son los mismos, en la medida en que el Decreto Ley de Amnistía es incompatible con los Convenios de Ginebra de 1949, ratificados por Chile en el año 1950.

En cuanto a las condiciones materiales para la aplicación del Derecho Internacional Humanitario, esto es la existencia de un conflicto armado, se puede decir lo siguiente: (i) es razonable concluir que en Chile hubo un conflicto armado interno de los mencionados en el Artículo 3 Común de los Convenios de Ginebra de 1949 el mismo día 11 de septiembre, fecha del golpe militar que derrocó al gobierno del Presidente Allende, y en los días inmediatamente posteriores, hasta que las fuerzas golpistas sofocaron toda resistencia armada; (ii) es razonable, igualmente, concluir que semejante tipo de conflicto armado existió nuevamente en Chile a partir de 1979 y por varios años, luego de que ciertos sectores de oposición al gobierno militar, en particular el Partido Comunista y el Partido de Izquierda Revolucionaria (MIR) iniciaron acciones organizadas de lucha armada; (iii) sin embargo, el gobierno militar no declaró estado de guerra interna en ninguno de esos períodos, es decir, el de breves días (el 11 de septiembre de 1973 y los días posteriores) o el de varios años (a partir de 1979); (iv) en cambio, con fecha 22 de septiembre de 1973, 11 días después del golpe, cuando podía estimarse que ya no existía un conflicto armado interno, el gobierno militar publicó el Decreto Ley № 5 por el cual dispone que el estado de sitio que había dictado previamente debía entenderse como tiempo de guerra para los efectos de la competencia de tribunales militares, así como de procedimiento penal y penas propias de dicho tiempo; (v) el Decreto Ley $N^{\circ} 5$ no declaró propiamente el estado de guerra interno, sino que se valió de una ficción o argucia para facilitar la represión judicial de los disidentes políticos y agravar sus consecuencias procesales y penales; (vi) en todo caso, como es sabido, la aplicación del Derecho Internacional Humanitario procede en caso de la existencia efectiva de un conflicto armado, haya o no una declaración oficial en ese sentido.

Por el contrario, caracterizar el asesinato del Sr. Almonacid como crimen contra la humanidad resulta técnicamente más controvertible. La Corte acierta al declarar que los crímenes contra la humanidad imponen una obligación internacional de enjuiciar y (si se les considera culpables)

19 Párr. 171, numeral 2. 
castigar a los perpetradores, y que no es permisible amnistiar tales conductas ${ }^{20}$. Sin embargo, no es rigurosa al aplicar el concepto de crimen contra la humanidad al caso que le tocaba decidir en Almonacid. En su análisis sobre si el crimen cometido contra el Sr. Almonacid Arellano podía o no constituir un crimen contra la humanidad ${ }^{21}$ la Corte dice ${ }^{22}$ que los diversos antecedentes jurídicos que expone en su razonamiento llevan a concluir que hay "amplia evidencia" de que en 1973, año de la muerte del Sr. Almonacid Arellano, el asesinato ejecutado en un contexto de ataque generalizado o sistemático contra la población civil era un crimen contra la humanidad. Ello bien puede ser sostenible, pero no se desprende de la argumentación ofrecida por la Corte. Obsérvese que ésta adopta un lenguaje semejante al del artículo 7 del Estatuto de Roma de 1998, que define los crímenes contra la humanidad, pero omite incluir el elemento "con conocimiento de dicho ataque" (es decir, conocimiento de un ataque generalizado o sistemático contra la población civil). Es muy probable que pueda sostenerse que quienes asesinaron al Sr. Almonacid Arellano poseían tal conocimiento, pero habría sido preciso fundamentar tal conclusión en el fallo. Incluso como paso lógico previo a considerar ese punto, es dudoso que pueda sostenerse, como lo hace la Corte, que en 1973 se había alcanzado tal desarrollo normativo en el derecho internacional. La afirmación de la Corte en ese sentido equivale a suponer que los avances de Derecho Internacional positivo en materias de gran importancia humanitaria son siempre o, por lo general, actos declarativos de normas consuetudinarias formadas con anterioridad.

A estas alturas, me veo obligado a expresar la esperanza de que no se malentienda este comentario. En mi concepto, el Decreto Ley de Amnistía de 1978 es espurio por razones éticas y jurídicas y no puede en ningún caso producir el efecto (si alguno pudiera producir) de amnistiar conductas que conforme al derecho internacional deben ser enjuiciadas y eventualmente castigadas, como es el caso de los crímenes de guerra y los crímenes contra la humanidad. El punto crucial es que es importante que las sentencias de la Corte, además de acertar en sus conclusiones generales y de conformarse a criterios básicos de justicia, se basen en argumentaciones jurídicas sólidas.

A mi juicio, son tres las razones que determinaron la argumentación de la Corte en Almonacid. Dos de ellas podrían llamarse criterios de justicia: por una parte aplicar pro persona principios en el juzgamiento del caso y, por otra, tomar una oportunidad para ampliar su jurisprudencia sobre una materia de trascendencia.

La tercera razón es técnico-jurídica. Sucede que en su sentencia de 4 de febrero de 2000, recaída sobre las excepciones preliminares del caso Las Palmeras, la Corte decidió aceptar dos de las excepciones interpuestas (con un voto disidente respecto de una de ellas) por el Estado de Colombia, relativas a la falta de competencia de la Corte para aplicar el Derecho Internacional Humanitario. El Estado de Colombia había expresado que no se oponía a que la Corte interpretara armónicamente los tratados, pero sí rechazaba que se pronunciara expresamente sobre supuestas violaciones al Artículo 3 Común de los Convenios de Ginebra de 1949. Dado que a la fecha de la muerte del Sr. Almonacid Arellano puede muy bien sostenerse que existía en Chile un conflicto armado del tipo contemplado en dicho Artículo 3 Común, la Corte evitó caracterizar su asesinato como crimen de guerra y argumentó -como ya queda dicho, de modo impreciso- que se trata de un crimen contra la humanidad.

En Almonacid, la Corte repudia el Decreto Ley № 2.19123. Sin embargo, en el párrafo 120 del fallo, junto con calificar dicho decreto como norma de autoamnistía, declara que más que considerar

\footnotetext{
20 Párrs. 105-114.

21 Párrs. 93-104.

22 Párr. 99.

23 Párrs. 115-122
} 
el proceso de adopción y la autoridad que lo emitió, atiende a su ratio legis, que es amnistiar graves hechos delictivos contra el derecho internacional cometidos por el gobierno militar. En cambio, en el voto razonado del juez Cançado Trindade la negación de la validez jurídica de las autoamnistías se basa en una gama más amplia de argumentos. Sin embargo, ni dicho voto razonado ni el fallo se hacen cargo de argumentos que surgen de la práctica y la doctrina del llamado campo de justicia transicional. Entre ellos, el hecho de que las autoamnistías suponen aprovecharse del propio dolo (mediante la usurpación de funciones legislativas) y que constituyen un obstáculo para el conocimiento de la verdad general y de casos particulares, como derecho en sí, como bases de un necesario reconocimiento social y como parte de un proceso de justicia penal, de reparaciones y de justicia restaurativa, entendida esta última como la que busca asegurar la dignidad, derechos e inclusión de quienes ha sido marginados, excluidos y reprimidos, con el fin último de avanzar hacia la construcción de una sociedad más justa.

Con respecto a diversos otros alcances de la obligación de investigar, perseguir, enjuiciar y, eventualmente, castigar ciertos crímenes contra el derecho internacional, la Corte tampoco se pronuncia, aunque ello difícilmente pueda reprochársele, ya que es una materia que dista de ser pacífica y que no ha sido suficientemente abordada por el derecho internacional y por la doctrina.

Entre otros puntos que se requiere dilucidar se cuentan los siguientes: (a) ¿La obligación de enjuiciar y castigar supone necesariamente imponer penas privativas de libertad y llevar a cabo procesos criminales como los reconocidos en la mayor parte de los países? ¿ $\mathrm{O}$ bien puede contemplar procedimientos alternativos consuetudinarios o, como en el caso de Sudáfrica, el otorgamiento de amnistías (con excepción de los crímenes que no puedan ser calificados de políticamente motivados) sujetas a la condición de una revelación pública y completa de lo ocurrido y de la participación del declarante? (b) Si una persona ha sido condenada por crimen de guerra o crimen contra la humanidad, ¿es legítimo que se beneficie de medidas ulteriores de clemencia, en la medida en que éstas no sean, de hecho, un modo de evadir los efectos de la justicia? 